\title{
TELAAH ALIRAN PENDIDIKAN PROGRESIVISME DAN ESENSIALISME DALAM PERSPEKTIF FILSAFAT PENDIDIKAN
}

\author{
H.A. Yunus \\ Universitas Majalengka
}

\begin{abstract}
ABSTRAK
Proses pendidikan melibatkan berbagai pihak, sekurang-kurangnya pendidik dan peserta didik. Partisipasi dari berbagai pihak menjadi modal untuk mencapai keberhasilan. Progresivisme dan esensialisme merupakan aliran filsafat pendidikan yang dapat diterapkan sebagai dasar epistemologi untuk mengembangkan pendidikan yang bersifat partisipasif dengan alasan: 1) Bahwa keduanya menghendaki agar tidak ada pendidikan bercorak otoriter, sejak berkembangnya aliran ini sampai sekarang; 2) Aliran ini menitikberatkan perhatiannya pada kemajuan Ilmu pengetahuan dan kebudayaan; 3) Pengalaman merupakan dinamika hidup; 4) Progresivisme tidak hanya mengakui akan adanya ide-ide, teori-teori, atau cita-cita, tetapi sesuatu yang ada itu harus bermakna bagi suatu kemajuan atau tujuan yang baik; 5) Progresivisme dan esensialisme mendorong manusia untuk memfungsikan jiwa untuk membina hidup yang dinamis dan tegar dalam menghadapi berbagai persoalan yang silih berganti.
\end{abstract}

Kata Kunci: Aliran Pendidikan, Progresivisme dan Esensialisme

\footnotetext{
${ }^{1}$ Penulis adalah Dosen Prodi PAI Fakultas Agama Islam Universitas Majalengka
} 


\section{Pendahuluan}

Pada dasarnya pendidikan adalah proses memanusiakan manusia secara manusiawi agar peserta didik memiliki kemanusiaan. Nilai-nilai kemanusiaan merupakan intisari dari tujuan pendidikan, baik dalam hal pembentukan kepribadian, keterampilan maupun sikap dan kemampuan untuk patuh kepada perintah Tuhan, taat beribadah, dan menjalankan tugas sebagai khalifah di muka bumi dengan sebaikbaiknya. Dengan kata lain, nilai-nilai kemanusiaan yang diharapkan adalah kesediaan seseorang untuk berserah diri kepada Tuhan sehingga memperoleh keselamatan dan kedamaian.

Banyak faktor yang menentukan keberhasilan pendidikan, diantaranya adalah faktor landasan filsafat, terutama dalam hal menentukan arah dan tujuan pendidikan yang diharmoniskan dengan nilai-nilai filsafat baik secara ontologis, epistemologis, maupun aksiologis.

Ontologis berkenaan dengan pertanyaan mengapa harus ada pendidikan, bagaimana merancang pendidikan, serta apa yang ingin dicapai setelah pendidikan dilakukan. Adapun ranah epistemologi berkenaan dengan proses dan pengetahuan apa yang akan digunakan dalam proses serta ilmu pengetahuan apa yang akan diperoleh peserta didik setelah proses ditempuh. Sedangkan aksiologi berkenaan dengan nilai-nilai kegunaan atau manfaat dari pendidikan tersebut.

Berkenaan dengan landasan-landasan epistemologi, terdapat berbagai aliran yang dapat digunakan dengan berbagai karakter dan kekhasannya. Dalam penelitian ini, telaah difokuskan kepada dua aliran yang sudah ada sejak lama, yakni aliran progresivisme dan esensialisme.

\section{Progresivisme}

\section{Perkembangan}

Semula, dalam menempuh perjalanan hidup dan kehidupannya selama berabadabad silam manusia menghadapi dunia ini hanya dengan kekuatan ototnya. Dengan cara tersebut tidak banyak yang dihasilkan, tidak banyak pula kemajuan yang dialami, sehingga berpengaruh kepada tingkat peradaban masyarakat. Tetapi, keadaan mulai berbeda setelah lahirnya ilmu pengetahuan yang teratur. Dengan ilmu pengetahuan banyak ide baru yang muncul, banyak benda budaya yang tercipta, banyak corak dalam menjalani kehidupan, bahkan seni pun terus berkembang.

Sejalan dengan hal itu, manusia secara berangsur mulai menyadari betapa hebatnya kemampuan yang dimilikinya ketika mempergunakan otak sejalan dengan tangan dan anggota badan lainnya secara bersamaan, maka terbayanglah harapan ke depan bahwa dunia ini dapat diperbaiki, lingkungan dapat dirubah sesuai dengan kebutuhan manusia.

Tetapi bukanlah karena kesadaran manusia yang berangsur-angsur terhadap hebatnya pengetahuan saja, bahkan ide tentang kemajuan pun pada akhirnya tumbuh dan disadari. Selain itu, lambat laun menusia menyadari pula bahwa dunia ini merupakan jalan bagi upaya pencapaian tujuan hidupnya.

Dari segi istilah, pada dasarnya kata progress merupakan kata baru yang baru bisa dipahami serta dimengerti maksud dan arti sebenarnya sekitar abad ke19. Tetapi tidak dapat dipungkiri bahwa maksud dari kata tersebut sekarang ini telah dipergunakan dan dikenal di dalam segala pengalaman hidup yang mengandung ide perbaikan dalam segala aspek kehidupan, seperti bidang politik, kemasyarakatan, hubungan kemanusiaan, ekonomi, kehidupan keluarga, perawatan anak, dan termasuk juga bidang kehidupan beragama.

Aliran filsafat progresivisme ini senantiasa berusaha mengembangkan asas kemajuan dalam semua realita, terutama dalam kehidupan untuk tetap survive terhadap semua tantangan hidup manusia. Kemudian, bagi yang menganut aliran ini dalam bertindak harus praktis, dalam 
melihat segala sesuatu harus mampu menemukan manfaat dari segi keunggulannya. Menurut Muis (2004), Progresivisme disebut instrumentalisme, eksperimental, atau environmentalisme. Disebut instrumentalisme, karena aliran ini beranggapan bahwa potensi atau kemampuan intelegensi manusia sebagai alat untuk hidup, untuk kesejahteraan, dan untuk mengembangkan kepribadian. Dinamakan eksperimental atau empirik karena aliran tersebut menyadari dan mempraktekkan asas eksperimen untuk menguji kebenaran suatu teori. Progresivisme dinamakan juga environmentalisme karena aliran ini menganggap bahwa lingkungan hidup ini mempengaruhi pembinaan kepribadian seseorang. (Muis, 2004).

$$
\text { Pendapat lain menyatakan }
$$
bahwa aliran progresivisme sepaham dengan psikologi pragmatisme yang berpendapat bahwa suatu keterangan itu benar kalau kebenaran itu sesuai dengan realitas, atau suatu keterangan akan dikatakan benar kalau kebenaran itu sesuai dengan kenyataan. Aliran progresivisme memiliki kemajuan dalam bidang ilmu pengetahuan yang meliputi ilmu hayat, antropologi, dan psikologi. Ilmu hayat berguna bagi manusia untuk mengetahui semua masalah dirinya secara biologis dan kehidupan. Ilmu antropologi berguna bagi manusia agar mengenal dirinya, bahwa manusia memiliki pengalaman dan kemampuan mencipta budaya, sehingga manusia dapat mencari dan menciptakan hal baru. Adapun psikologi berguna bagi manusia bahwa dirinya mampu berpikir, bahkan memikirkan tentang dirinya, tentang lingkungan, pengalaman masa lalu, harapan di masa depan, sifat-sifat alam, serta dapat menguasai dan mengatur alam dan lingkungan untuk memenuhi kebutuhannya.

\section{Pandangan Tentang Pendidikan}

\section{a. Pendidikan}

Aliran progresivisme ini pernah berjaya di Amerika. Dalam pendidikan, progresivisme merupakan bagian dari gerakan reformis umum bidang sosialpolitik yang menandai kehidupan orang Amerika.

Progresivisme merupakan teori yang mucul dalam reaksi terhadap pendidikan tradisional yang selalu menekankan kepada metode formal pengajaran. Pada dasarnya teori ini menekankan beberapa prinsip, antara lain; 1) Proses pendidikan berawal dan berakhir pada peserta didik; 2) Peserta didik adalah sesuatu yang aktif, bukan pasif; 3) Peran guru hanya sebagai fasilitator, pembimbing, dan pengarah; 4) Sekolah harus menciptakan iklim yang bersifat kooperatif dan demokratif; 5) Aktifitas pembelajaran lebih focus pada pemecahan masalah bukan untuk mengajarkan materi kajian.

Menurut pandangan progresivisme, proses pendidikan memiliki dua bidang garapan, yaitu psikologis dan sosiologis. Dilihat dari segi psikologis, pendidik harus dapat mengetahui potensi dan daya yang ada pada peserta didik untuk dikembangkan. Dengan mengenal hal tersebut, pendidik dapat memilih cara yang tepat dan landasan apa yang akan digunakan. Jika memperhatikan peran pandangan progresivisme di beberapa negara maju, psikologi yang banyak digunakan adalah aliran behaviorisme dan pragmatisme. Hal ini sejalan dengan teori bahwa aliran progresivisme disebut juga instrumentalisme, eksperimental, atau environmentalisme yang erat kaitannya dengan alat, pengalaman, lingkungan, serta kemajuan dan manfaat dari suatu aktivitas yang dilakukan, termasuk aktivitas pendidikan.

Dilihat dari segi sosiologis, pendidik harus mengetahui ke mana potensi dan daya itu harus dibimbing agar potensi yang dimiliki peserta didik dapat dirubah menjadi sesuatu yang berguna bagi anak tersebut. 


\section{b. Kurikulum}

Dalam pendidikan, terutama jalur pendidikan formal, kurikulum memegang peranan penting. Kurikulum sebagai jantung pendidikan tidak saja dimaknai sebagai seperangkat mata pelajaran yang dirancang untuk disajikan dalam sebuah program sekolah, melainkan memiliki arti yang lebih luas. Oleh sebab itu, para pakar memaknai kurikulum dengan titik berat yang berbeda. Bahkan ada yang melihat dari arti sempit dan arti luas, ada juga yang melihat dari segi fungsi atau kegunaannya, ada juga yang melihat dari segi ruang lingkupnya.

Musgave menekankan pengertian kurikulum pada ruang lingkup, terutama yang berkenaan dengan pengalaman belajar, baik pengalaman di luar maupun di dalam lingkungan sekolah. Aktifitas dan pengalaman peserta didik seyogyanya selalu berada dalam pengawasan lembaga pendidikan (sekolah). Kemudian, Hirts dan Petters mengemukakan pengertian kurikulum dengan menekankan pada aspek fungsional. Dalam hal ini, kurikulum diposisikan sebagai rambu-rambu yang menjadi acuan dalam proses pendidikan, khususnya dalam pembelajaran.

Progresivisme memiliki pandangan bahwa kurikulum merupakan pengalaman mendidik, bersifat eksperimental, dan adanya rencana serta susunan langkah yang teratur. Pengalaman belajar berupa pengalaman apa saja yang serasi dengan tujuan menurut prinsip-prinsip yang telah digariskan dalam pendidikan, di mana setiap proses pembelajaran yang ada membantu pertumbuhan dan perkembangan peserta didik.

Dalam prakteknya, progresivisme merupakan aliran pendidikan yang berpusat pada siswa. Secara lebih spesifik, proses pembelajaran penekanan lebih besar diarahkan pada kreativitas, aktivitas, belajar naturalistik, hasil belajar dunia nyata (empiris), dan pengalaman teman sebaya. Menurut Dewey, dalam konteks sekolah progresivisme lebih menekankan pada peserta didik dan minatnya dibanding pada mata pelajaran itu sendiri. Oleh karena itu, muncul istilah child centered curriculum dan child centered school. Progresivisme mempersiapkan peserta didik masa kini dibanding masa depan yang belum jelas. Hal ini diungkapkan juga oleh Dewey, bahwa pendidikan adalah proses dari kehidupan dan bukan persiapan masa yang akan datang. Implikasinya, pandangan Dewey tentang pendidikan yang berlandaskan aliran progresivisme menyatakan bahwa aktifitas peserta didik perbanyak terlebih dahulu dalam berpartisipasi pada kegiatan fisik, baru kemudian diarahkan pada peminatan (Barnadib, 1997).

Dalam ajaran Islam, pendidikan menempati posisi yang tinggi dan strategis, karena hanya melalui pendidikan orang dapat memperoleh ilmu, dan dengan ilmu orang mengenal dirinya, Tuhannya, dan alam semesta. Selain itu, hanya dengan pendidikanlah seseorang dapat memahami posisi dirinya di samping posisi Tuhan, sehingga akan muncul kesadaran tentang ibadah dan mematuhi Tuhannya. Dalam urusan dunia, dengan pendidikan manusia akan mampu menghadapi berbagai rintangan selama menjalani hidup dan kehidupannya.

Khusus ilmu, dalam ajaran Islam merupakan hal yang sangat penting, sehingga menuntut ilmu hukumnya wajib. Dibandingkan dengan hal lain, ilmu memiliki keunggulan luar biasa, bahkan ibadahpun tidak akan diterima tanpa didasari ilmu. Demikian pula apabila dikaitkan dengan strata sosial. Tinggi rendahnya derajat seseorang, di samping iman dan takwa juga di tentukan oleh kualitas keilmuannya. Oleh karena ilmu dapat menentukan kualitas seseorang, maka keberadaan pendidikan sebagai sebuah proses perolehan ilmu menjadi sangat penting. Karena itu, proses pencarian ilmu harus terus menerus dilakukan, dimana pun kdan apanpun, baik sekarang maupun di masa yang akan datang. 
Essensi pendidikan dalam ajaran Islam dipahami sebagai sebuah proses transformasi dan internalisasi nilai-nilai ajaran Islam terhadap peserta didik, melalui pengembangan potensi sesuai fitrahnya agar memperoleh keseimbangan hidup dalam semua aspeknya, terutama keseimbangan antara dunia dan akhirat. Dengan demikian fungsi pendidikan Islam pada hakikatnya adalah proses pewarisan nilai-nilai Islami untuk menggembangkan potensi manusia, dan sekaligus proses produksi nilai-nilai budaya Islam baru sebagai hasil interaksi potensi dengan lingkungan dan konteks zamannya sesuai ruang lingkup filsafat pendidikan Islam di atas mengandung indikasi bahwa filsafat pendidikan Islam sebagai sebuah disiplin ilmu (Nata, 1996).

Dalam hal pendidikan secara umum, kurikulum sebagai inti pendidikan tidak saja dimaknai sebagai seperangkat rangkaian mata pelajaran yang ditawarkan sebagai jiwa dalam sebuah program pendidikan di sekolah, tetapi kurikulum pun mengandung makna yang lebih luas. Oleh karena itu, para pakar memaknai kurikulum dengan titik berat yang berbeda. Hirts dan Petters menekankan pada aspek fungsional, dalam hal ini kurikulum diposisikan sebagai rambu-rambu yang menjadi acuan dalam proses pembelajaran. Selain itu, kurikulum dijadikan acuan juga oleh pengelola lembaga pendidikan, karena sarana dan prasarana serta pendukung lainnya harus disiapkan agar benar-benar sesuai dengan tuntutan kurikulum. Makna lain dari kurikulum dikemukakan oleh Musgave yang lebih menekankan pada ruang lingkup pengalaman belajar yang meliputi pengalaman di luar maupun di dalam sekolah. Pendapat Musgave ini sejalan dengan pendapat Stephen yang menyatakan bahwa kurikulum mencakup semua materi pelajaran, aktivitas dan pengalaman peserta didik, dimana ia berada dalam pengawasan lembaga pendidikan, baik yang terjadi di luar maupun di dalam kelas.

\section{c. Pendidik}

Di Indonesia, menurut UndangUndang No. 14 tahun 2004 tentang Guru dan Dosen, pada Pasal 1 ayat 1 dikemukakan bahwa "Guru adalah pendidik profesional dengan tugas utama mendidik, mengajar, membimbing, mengarahkan, melatih, menilai, dan mengevaluasi peserta didik pada pendidikan anak usia dini jalur pendidikan formal, pendidikan dasar, dan pendidikan menengah". Dalam UU No. 20 tahun 2003 tentang Sistem Pendidikan Nasional "Pendidik adalah tenaga kependidikan yang berkualifikasi sebagai guru, dosen, konselor, pamong belajar, widyaiswara, tutor, instruktur, fasilitator, dan sebutan lain yang sesuai dengan kekhususannya, serta berpartisipasi dalam menyelenggarakan pendidikan".

Menurut pandangan filsafat progresivisme guru adalah penasihat, pembimbing, pengarah dan bukan sebagai orang pemegang otoritas penuh yang dapat berbuat apa saja (otoriter) terhadap muridnya. Guru disebut sebagai pembimbing karena mempunyai ilmu pengetahuan dan pengalaman yang banyak di bidang pendidikan, memahami karakter peserta didik yang secara otomatis (semestinya) guru mampu menjadi penasihat manakala peserta didik mengalami jalan buntu dalam memecahkan persoalan yang dihadapi. Oleh karena itu peran utama pendidik adalah membantu peserta didik bagaimana mereka harus belajar dengan diri mereka sendiri, sehingga peserta didik akan berkembang menjadi orang dewasa yang mandiri dalam lingkungannya yang akan selalu berubah.

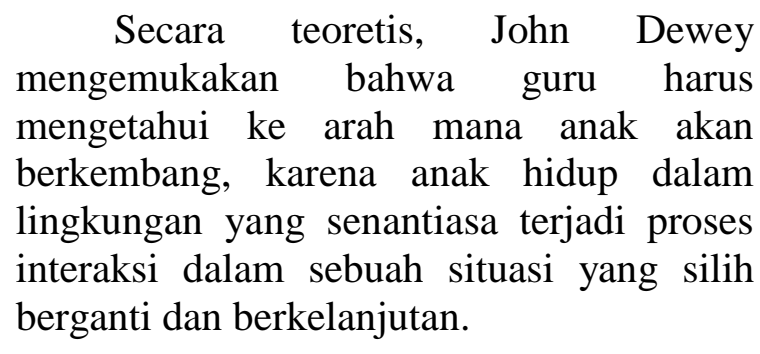

Dalam penerapannya, prinsip keberlanjutan mengandung arti bahwa masa depan harus selalu diperhitungkan di setiap 
tahapan dalam proses pendidikan. Dalam hal ini, guru harus mampu menciptakan suasana kondusif di dalam kelas dengan cara membangun kesadaran bersama dari setiap individu dalam upaya mencapai tujuan bersama. Upaya tersebut sesuai dengan tanggungjawab masing-masing dalam konteks pembelajaran di dalam kelas, dan selalu konsisten pada tujuan tersebut (Muis, 2004).

Berkenaan dengan hal tersebut, teori progresivisme menyatakan bahwa tugas pendidik adalah sebagai pembimbing aktivitas peserta didik dan berusaha untuk memberikan kemungkinan terhadap terciptanya lingkungan terbaik yang memungkinkan terjadinya proses belajar. Guru sebagai pembimbing, tidak boleh menonjolkan diri, melainkan harus bersikap demokratis dan memperhatikan hak-hak alamiah dari para peserta didik secara keseluruhan. Pendekatan yang digunakan dalam proses ini adalah pendekatan psikologis dengan keyakinan bahwa memotivasi lebih penting daripada sekedar memberi informasi. Pendidik dan peserta didik bekerja sama dalam mengembangkan program belajar dan aktualisasi potensi peserta didik dalam kepemimpinan dan kemampuan lain yang dikehendaki dalam pendidikan.

Dengan demikian dalam teori ini pendidik harus memiliki kelebihan dibanding manusia lainnya, antara lain jeli, teliti, telaten, konsisten, luwes, dan cermat dalam mengamati apa yang menjadi kebutuhan peserta didik, juga sanggup menguji dan mengevaluasi kepampuankemampuan peserta didik dalam tataran praktis dan realistis. Hasil evaluasi menjadi acuan untuk menentukan pola dan strategi pembelajaran selanjutnya. Dengan kata lain pendidik harus mempunyai kreatifitas dalam mengelola peserta didik, dalam arti akan berkembang dan bervariasi sebanyak variasi para peserta didik yang berada di bawah tanggungjawabnya.

\section{d. Peserta Didik}

Di Indonesia, menurut UU No. 20 tahun 2003 tentang Sistem Pendidikan Nasional, pada Pasal 1 angka 4, dinyatakan bahwa "Peserta didik adalah anggota masyarakat yang berusaha mengembangkan potensi diri melalui proses pembelajaran yang tersedia pada jalur, jenjang, dan jenis pendidikan tertentu".

Teori progresivisme menempatkan peserta didik pada posisi sentral dalam melakukan pembelajaran. karena peserta didik mempunyai kecenderungan alamiah untuk belajar dan menemukan sesuatu tentang dunia di sekitarnya dan juga memiliki kebutuhan-kebutuhan tertentu yang harus terpenuhi dalam kehidupannya. Kecenderungan dan kebutuhan tersebut akan memberikan kepada peserta didik suatu minat yang jelas dalam mempelajari berbagai persoalan.

Peserta didik adalah makhluk yang memiliki kelebihan dibanding dengan makhluk-makhluk lain karena peserta didik memiliki potensi kecerdasan. Oleh karena itu, setiap peserta didik mempunyai potensi atau kemampuan sebagai bekal untuk menghadapi kehidupan dan memecahkan permasalahan-permasalahan yang mungkin merintanginya. Berkenaan dengan hal ini, tugas guru atau pendidik adalah meningkatkan kecerdasan potensial yang telah dimiliki sejak lahir menjadi kecerdasan realitas dalam lapangan pendidikan untuk dapat merespon segala perubahan yang terjadi di lingkungan di mana ia hidup dan beraktifitas. Pandangan progresivisme mengenai belajar bertumpu pada pandamgan peserta didik sebagai mahluk yang mempunyai kelebihan dibandingkan mahluk lain (Barnadib. 1994).

Secara institusional sekolah sebagai lembaga pendidikan harus memelihara dan manjamin kebebasan berpikir dan berkreasi kepada para peserta didik, sehingga mereka memilki kemandirian dan aktualisasi diri. Namun demikian, pendidik tetap berkewajiban mengawasi dan mengontrol mereka guna meluruskan kesalahan yang 
dihadapi peserta didik, khususnya dalam metodologi berpikir. Dengan demikian prasyarat yang harus dilakukan oleh peserta didik adalah sikap aktif dan kreatif, bukan hanya menunggu kedatangan guru dalam mengisi dan mentransfer ilmunya kepada mereka. Peserta didik tidak boleh diperlakukan seperti bejana kosong yang akan diisi oleh penggunanya. Jika yang terjadi demikian, maka proses pembelajaran hanya berwujud transfer of knowledge dari seorang guru kepada murid. Tentu saja cara demikian tidak akan membawa hasil apalagi mencerdasakan sehingga dapat dikatakan bahwa upaya mencapai tujuan pendidikan mengalami kegagalan.

\section{e. Pandangan Belajar}

Menurut Gagne (1977), "belajar merupakan sejenis perubahan yang diperlihatkan dalam perubahan tingkah laku, yang kebaradaannya berbeda dari sebelum individu ada dalam situasi belajar dan sesudah melakukan tindakan yang serupa itu". Perubahan terjadi akibat adanya suatu pengalaman atau latihan. Berbeda dengan perubahan yang terjadi tanpa sengaja atau serta-merta terjadi akibat perilaku yang bersifat naluriah. Hal ini berbeda dengan teori pendidikan progresivisme yang intinya bagaimana mengajarkan cara belajar yang tepat, sehingga seseorang dapat belajar setiap saat dari realitas secara mandiri, baik di dalam maupun di luar sekolah, pada saat, sedang, ataupun setelah menyelesaikan pendidikan formal. Dengan demikian sekolah akan dapat menghasilkan individu-individu yang cerdas, kreatif, dan inovatif yang pada gilirannya nanti dapat melakukan transformasi budaya positif ke arah yang lebih baik dari masyarakat yang progresif. Jika seseorang telah memiliki kemampuan seperti itu, di mana pun berada akan mampu bertahan dari berbagai hambatan dan mampu memecahkan masalah kehidupan.

Dalam prakteknya, pendidikan yang berlandaskan aliran progresivisme memerlukan model yang sesuai. Di
Indonesia, pendidikan seringkali mendapat kritikan dari berbagai pihak, karena dianggap belum memiliki model yang jelas dengan acuan yang pasti, bahkan ada yang menganggap bernuansa coba-coba. Alasan yang sering dikemukakan karena penampilan pendidikan itu sendiri masih abstrak dan masih belum menyentuh realitas budaya Indonesia yang khas. Berkaitan dengan konteks pendidikan modern saat ini, pendidikan di Indonesia lebih mengedepankan corak atau pola pemikiran rasionalis-empiris, kemudian berkembang berbagai konsep atau teori pendidikan nativisme, empirisme, dan konverguensi. Di samping itu, muncul pula aliran progresivisme, essensialisme, perenialisme, dan rekonstruksionisme.

Dalam konsep seperti itu, peserta didik diberi kebebasan untuk mengembangkan bakat dan kemampuannya baik secara fisik maupun cara berpikirnya. Peserta didik bebas juga dirinya tanpa terhambat oleh rintangan yang dibuat oleh orang lain. Dengan demikian, progresivisme tidak menyutujui pendidikan otoriter,sebab akan mematikan daya kreasi peserta didik baik secara fisik mapupun psikis. (Barnadib, 1997).

Berkaitan dengan hal tersebut, John Dewey sebagai salah seorang tokoh progresivisme, memiliki peranan yang cukup besar. Dimana alirannya ini sangat berpengaruh terhadap pembaharuan pendidikan dan dengan pandangannya, progresivisme dianggap sebagai the liberal road to culture dalam artian bahwa liberal berarti berani toleran dan transparan.

\section{Esensialisme}

\section{Pengertian}

Pada dasarnya, filsafat pendidikan esensialisme bertitik tolak dari kebenaran yang dianggap telah terbukti selama berabad-abad lamanya. Jika dilihat dari segi proses perkembangannya, esensialisme merupakan perpaduan antara ide-ide filsafat 
idealisme dan realisme. Aliran tersebut akan tampak lebih mantap dan kaya akan ide-ide, apabila hanya mengambil salah satu dari aliran atau posisi sepihak. Pertemuan dua aliran tersebut bersifat elektik, yakni keduanya berposisi sebagai pendukung, tidak ada yang melebur menjadi satu atau tidak melepaskan identitas dan ciri masingmasing (Anwar, 2015).

\section{Karakteristik Essensialisme}

Esensialisme yang bekembang pada zaman renaissance mempunyai tinjauan yang bebeda dengan progresivisme, yaitu mengenai pendidikan dan kebudayaan. Progresivisme menganggap bahwa pendidikan penuh dengan fleksibilitas, serba terbuka untuk perubahan, tidak ada keterkaitan dengan doktrin tertentu, toleran, serta nilai-nilai yang dimilikinya dapat berubah dan berkembang. Oleh karena itu, aliran esensialisme memandang bahwa pendidikan bertumpu pada dasar pandangan fleksibilitas dalam segala bentuk yang dapat menjadi sumber timbulnya pandangan yang berubah-ubah, mudah goyah dan kurang terarah, tidak menentu dan kurang stabil. Maka dari itu, idealnya pendidikan harus berpijak di atas nilai-nilai yang sekiranya dapat mendatangkan kestabilan, telah teruji oleh waktu, tahan lama, serta nilai-nilai yang memiliki kejelasan dan telah terseleksi (Anwar,2015). Adapun nilai-nilai yang dianggap dapat dijadikan pijakan, yaitu nilai-nilai yang berasal dari kebudayaan dan filsafat yang korelatif. Puncak refleksi dari gagasan ini adalah pada pertengahan abad kesembilan belas (Barnadib, 1997).

\section{Konsep Pendidikan Esensialisme}

Kaum esensialis mengemukakan bahwa sekolah harus melatih, mengajar, atau mendidik peserta didik untuk mampu berkomunikasi dengan jelas dan logis, Keterampilan-keterampilan inti kurikulum harus berupa membaca, menulis, berbicara dan berhitung. Selain itu, sekolah bertanggungjawab untuk memperhatikan penguasaan peserta didik terhadap keterampilan-keterampilan tersebut, karena implementasi kurikulum membutuhkan dukungan media, sarana, dan lingkungan yang memadai. Menurut filsafat esensialisme, pendidikan sekolah harus bersifat praktis dan memberi pengajaran yang logis dan mampu mempersiapkan suatu keterampilan bagi kehidupan peserta didik. Dalam hal ini, sekolah tidak boleh mempengaruhi atau menetapkan kebijakan sosial.

\section{a. Tujuan Pendidikan}

Dalam konsep essensialisme, pendidikan bertujuan untuk meneruskan warisan budaya dan warisan sejarah melalui pengetahuan inti yang terakumulasi dan telah bertahan dalam kurun waktu yang lama.

Budaya tersebut merupakan suatu kehidupan yang telah teruji oleh waktu dalam tempo lama. Selain itu tujuan pendidikan esensialisme adalah mempersiapkan manusia untuk hidup. Namun demikian bukan berarti sekolah lepas tanggung jawab, akan tetapi memberi kontribusi tentang bagaimana merancang sasaran mata pelajaran sedemikian rupa, yang pada akhirnya memenuhi kebutuhan peserta didik untuk mempersiapkan diri dalam menghadapi kehidupan.

\section{c. Kurikulum}

Beberapa tokoh aliran esensialisme memandang bahwa kurikulum yang digunakan adalah kurikulum yang berpusat pada mata pelajaran atau subjek matter centered dan berpangkal pada landasan ideal dan organisasi yang kuat. Penguasaan materi kurikulum tersebut merupakan dasar yang bersifat essensialisme general education yangdiperlukan dalam hidup. Belajar dengan tepat berkaitan dengan disiplin yang diyakini akan mampu mengembangkan pikiran peserta didik dan sekaligus membuatnya sadar akan dunia fisik di sekitarnya (Barnadib, 1997). 
Dengan demikian, tujuan umum aliran esensialisme adalah membentuk pribadi bahagia di duni dan akhirat. Untuk mencapai tujuan tersebut isi pendidikan mencakup ilmu pengetahuan, kesenian dan segala hal yang mampu menggerakan kehendak manusia. Kurikulum sekolah bagi esensialisme merupakan semacam miniatur dunia yang bisa dijadikan sebagai ukuran dari suatu kenyataan, kebenaran dan kegunaan. Maka dalam proses perkembangannya, kurikulum esensialisme menerapkan berbagai pola kurikulum, seperti pola idealisme, realisme, behavriorisme, dan sebagainya sehingga peranan lembaga pendidikan formal atau sekolah dalam menyelenggarakan pendidikan dapat berfungsi sesuai dengan prinsip-prinsip dan kenyataan sosial yang ada di lingkungan masyarakat.

\section{d. Peranan Guru dan Sekolah.}

Peranan sekolah adalah memelihara dan menyampaikan warisan budaya dan sejarah pada generasi muda dewasa ini, melalui hikmat dan pengalaman yang terakumulasi dari disiplin tradisional. Selanjutnya mengenai peranan guru banyak persamaan dengan perenialisme. Guru memegang peran lebih khusus, di mana guru dianggap sebagai seorang yang menguasai lapangan, subjek khusus dan merupakan model yang baik untuk digugu dan ditiru. Guru merupakan orang yang mengusai pengetahuan, ilmu. Dalam pendidikan formal, kelas berada di bawah pengaruh dan pengawasan guru (Barnadib, 1997).

\section{e. Prinsip-prinsip pendidikan}

Prinsip-prinsip pendidikan yang dianut aliran esensialisme adalah sebagai berikut :

1) Pendidikan harus dilakukan melalui usaha keras, karena pendidikan tidak begitu saja timbul dari dalam diri siswa.

2) Inisiatif dalam pendidikan ditekankan pada guru bukan pada siswa.
3) Inisiatif proses pendidikan adalah asimilasi dari mata pelajaran yang telah ditentukan.

4) Sekolah harus mempertahankan metode-metode trasdisional yang bertautan dengan disiplin mental.

5) Tujuan akhir pendidikan adalah untuk meningkatkan kesejahteraan umum merupakan tuntutan demokrasi yang nyata.

6) Metode-metode tradisional yang bertautan dengan disiplin mental merupakan metode-metode yang diutamakan dalam proses pendidikan di sekolah.

Dengan demikian, pendidikan yang berlandaskan aliran essensialisme berusaha mengenal potensi peserta didik untuk dikembangkan melalui upaya lembaga pendidikan secara sistemik. Dalam hal ini peserta didik didorong untuk belajar sendiri dengan bimbingan dan arahan guru, sedangkan metode tradisional digunakan sebagai upaya pembentukan mental peserta didik melalui internalisasi nilai-nilai budaya yang telah mengakar di masyarakat di mana sekolah itu berada, dalam arti proses pendidikan beserta pembentukan mental peserta didik tidak terlepas dari budaya yang telah teruji dan terbukti unggul di masyarakat bersangkutan.

\section{Telaah Komparasi}

Aliran filsafat progresivisme dan essensialisme merupakan buah pemikiran filsuf barat. Kedua aliran tersebut telah diterapkan di negara-negara barat setelah teori tersebut dipublikasikan oleh tokoh penemunya. Para penganut aliran essensialisme sendiri, dapat mengkritik praktek pendidikan progresivisme karena telah diterapkan dan terlihat hasilnya, diantaranya adalah peserta didik diberi kebebasan mengembangkan potensi dirinya didorong oleh guru yang berfungsi sebagai penunjuk jalan. Dari segi keilmuan memang tampak berkembang pesat, karena peserta didik didorong untuk aktif dan 
kreatif didampingi oleh guru sebagai pasilitator, tetapi terdapat kelemahan dari segi mental dan kering dari nilai-nilai budaya.

Oleh karena itu, kaum essensialis mengemukakan konsep dan gagasan praktek pendidikan yang lebih mementingkan dasar nilai-nilai moral yang diambil dari budaya yang telah digunakan selama berabad-abad di masyarakat. Artinya, substansi pendidikan harus berakar pada budaya yang ada di masyarakat di mana lembaga pendidikan itu berada. Oleh karena itu, penggunaan metode pendidikan harus benar-benar dikuasai guru yang memiliki ilmu pengetahuan yang tinggi. Metode tradisional dianggap paling cocok, karena telah terbukti mampu mewariskan nilai-nilai budaya lokal secara turun temurun. Sifatnya tradisional tetapi telah teruji keberhasilannya. Selain itu, untuk mengendalikan agar peserta didik tidak diberi kebebasan tanpa batas, kaum essensialis mengemukakan pandangannya bahwa sekolah harus mampu menjadi pengendali (kontrol) terhadap proses pendidikan, sehingga pencapaian tujuan sesuai dengan apa yang diinginkan.

Di Indonesia, landasan pendidikan yang mengakar kepada filsafat tersebut, paling tidak landasan progresivisme dan esensialisme belum terbentuk dan nampak secara jelas. Bahkan terdapat kesan dari opini publik bahwa praktek pendidikan di Indonesia bernuansa coba-coba, setiap paradigma yang muncul dikait-kaitkan dengan pola yang pernah diterapkan di negara lain. Padahal, apabila dikaji secara cermat berbagai teori telah ada, tinggal bagaimana para pengambil kebijakan mensikapinya. Secara umum, filsafat yang telah terbentuk secara nyata di Indonesia baru filsafat Pancasila, aliran filsafat lainnya hanya dirujuk secara teoretis parsial.

Mensikapi dua aliran filsafat yang memiliki karakter berbeda, untuk dapat diterapkan dalam sistem pendidikan memang bukan pekerjaan gampang. Tetapi secara sederhana, setelah dikaji keunggulan dan kelemahan masing-masing, bisa saja keunggulan dari kedua aliran tersebut digabungkan, dalam arti satu sama lain saling melengkapi. Persis seperti landasan pendidikian secara psikologis, antara nativisme dengan behaviorisme dapat diharmoniskan. Selain daripada itu, bagi bangsa Indonesia yang mayoritas muslim, dapat juga mempertimbangkan filsafat pendidikan Islam.

\section{Kesimpulan}

Upaya memanusiakan manusia melalui pendidikan memerlukan paradigma yang jelas, guna dijadikan dasar dalam penetapan tujuan yang ingin dicapai. Banyak aliran filsafat yang dapat dijadikan acuan sebagai landasan, diantaranya adalah aliran progresivisme dan essensialisme yang masing-masing memiliki karakter dan ciri tersendiri.

Teori pendidikan yang dirancang berdasarkan filsafat progresivisme yang digagas Jhon Dewey, pada dasarnya mengutamakan lima hal, yaitu : a) Kurikulum yang baik disusun berdasarkan pengalaman edukatif bersifat eksperimental, disusun secara sistematis dan teratur serta tidak memaksakan diri untuk mengikuti kehendak pembuat kurikulum. b) Guru harus memiliki keunggulan dalam bidang ilmu pengetahuan dan sekaligus menguasai bidang ilmu tersebut. Dalam proses mendidik, guru tidak sepatutnya bertindak otoriter terhadap peserta didik, sehingga tugas guru adalah mengarahkan dan membimbing bagaimana cara belajar yang baik dan benar bagi peserta didik. Dalam hal ini, guru dapat dikatakan memiliki fungsi sebagai petunjuk jalan yang bijak. c) Peserta didik memiliki potensi masing-masing (individual) yang harus diberi kesempatan untuk berkembang secara wajar, aktif, kreatif, dan memiliki kebebasan untuk mengaktualisasikan dirinya 
dalam menentukan langkah dan tujuannya. d) Lingkungan merupakan hal penting yang tidak dapat dipisahkan dengan proses pendidikan sebagai penunjang keberhasilan. e) Metode yang digunakan dalam proses pendidikan harus diutamakan dibanding materi ajar, karena metode menunjang proses.

Pendidikan esensialisme merupakan suatu aliran yang kurang setuju terhadap praktek pendidikan progressivisme, dengan alasan bahwa pergerakan progresivisme dianggap akan merusak standar intelektual dan moral kaum muda dengan diberikannya kebebasan. Bagi aliran essensial, metode yang digunakan adalah metode tradisional yang menekankan pada inisiatif guru. Dalam hal ini, guru harus orang terdidik dan menguasai ilmu pengetahuan. Selain itu, seluruh aktifitas kelas harus berada di bawah kendali dan penguasaan guru. Secara kelembagaan, esensialis menginginkan agar sekolah berfungsi sebagai subjek proses pewarisan budaya dan sejarah yang mengandung nilainilai luhur dari para filosof sebagai ahli pengetahuan dimana nilai-nilai kebudayaan itu masih tetap terjaga dan diterapkan dalam tata kehidupan seharihari. Nilai-nilai moral yang berakar pada budaya masyarakat dijadikan dasar bagi pembentukan mental para peserta didik.

Di Indonesia, para pengambil kebijakan bidang pendidikan perlu meningkatkan intensitasnya dalam mengkaji aliran-aliran filsafat tersebut guna diambil manfaatnya demi kemajuan pendidikan secara menyeluruh. Mewaspadai kelemahan disertai dengan mempertimbangkan keunggulan dari aliran progresivisme dan esensialisme merupakan tindakan bijak.

\section{DAFTAR PUSTAKA}

Abudin, Nata. 1996. Filsafat Pendidikan Islam. Ciputat: Wacana Ilmu dan Pemikiran.
2003. Metodologi Studi Islam, Jakarta: Raja Grafindo Persada.

Anwar, Muhammad. 2015. Filsafat Pendidikan. Jakarta: Prenada Media Group As'adi.

Anwar, Saeful. 2007. Filsafat Ilmu AlGhazali Dimensi Ontologi dan Aksiologi. Bandung: CV. Pustaka Setia.

Abdullah, M. Yatimin. 2007. Studi Akhlak dalam Perspektif Al-Qur'an. Jakarta: Amzah.

Al-Abrasyi, Muhammad, Athiyah. 1974. Dasar-Dasar Pokok Pendidikan Islam. terj. Bustami Abdul Ghani dan Bohar Bahri. Jakarta: Bulan Bintang.

Arikunto, Suharsimi. 2002. Prosedur Penelitian Suatu Pendekatan Praktek. Jakarta: PT. Rineka Cipta.

Barnabid, Imam. 1997. Filsafat Pendidikan, Sistem dan Metode, Yogyakarta: Andi Offset

1994. Filsafat Pendidikan, Sistem dan Metode. Yogyakarta.

Djumransyah. 2004. Filsafat Pendidikaan, Malang: Bayu Media.

Edward, P. dan Yusnadi. 2015. Filsafat Pendidikan, Medan: UNIMED Press.

Muis, I.S. (2004). Pendidikan Partisiptif Menimbang Konsep Fitrah dan Progesivisme Jhon Dewey, Yogyakarta: Safaria Insania Press.

Pidarta, M. 2000. Landasan Kepedidikan, Jakarta : Rineka Cipta.

Tafsir, Ahmad. 2004. Filsafat Ilmu Mengurai Ontologi, Epistimologi dan Aksiologi Pengetahuan, Bandung: Remaja Rosdakarya. 